\title{
Collaborative approaches for Target ID in neglected diseases: identifying new antimalarial targets
}

\author{
Maria Jose Lafuente ${ }^{1 *}$, Sonja Guidelli-Disse ${ }^{2}$, Carolyn Selenski ${ }^{3}$, Joel Lelievre ${ }^{1}$, Timothy Willson ${ }^{3}$, \\ Francisco Javier Gamo ${ }^{1}$, Gerard Drewes ${ }^{2}$, Omar Vandal $^{4}$, Luis Ballell-Pages ${ }^{1}$ \\ From Challanges in malaria research: Core science and innovation \\ Oxford, UK. 22-24 September 2014
}

Malaria is a global health problem that causes significant mortality and morbidity, with more than 1 million deaths per year caused by $P$. falciparum. Most antimalarial drugs face decreased efficacy due to the spread of resistance. Most of the current compounds used for malaria treatment share related mechanisms of action so, there is an urgent need to identify new tractable targets to enable next generation of antimalarial drugs.

The malaria drug discovery community has embraced phenotypic screening approaches as the strategy of choice for the generation of novel chemical starting points for Lead Optimization programs. Determining the mode of action for novel whole cell hits remains a challenge, but new technologies, including genetics, chemoinformatics and proteomics are proving successful.

A chemical proteomics platform aimed at identifying antimalarial targets has been established. This platform is supported by The Bill \& Melinda Gates Foundation and encompasses chemical probe synthesis, biological material preparation, pull down experiments and LC-MS proteinlead family characterization for chemical families of interest. Candidate scaffolds to be investigated through this platform are selected based on their biological profile by a join Steering Committee constituted by both GSK and BMGF members.

\section{Authors' details}

${ }^{1}$ DDW Malaria DPU GSK, Tres Cantos, Madrid, Spain. ${ }^{2}$ Cellzome GSK Heidelberg, Germany. ${ }^{3}$ R\&D Platform Technology \& Science, North Carolina, USA. ${ }^{4}$ The Bill and Melinda Gates Foundation, Seattle, USA.

Published: 22 September 2014

'DDW Malaria DPU GSK, Tres Cantos, Madrid, Spain

Full list of author information is available at the end of the article
doi:10.1186/1475-2875-13-S1-P54

Cite this article as: Lafuente et al: Collaborative approaches for Target ID in neglected diseases: identifying new antimalarial targets. Malaria Journal 2014 13(Suppl 1):P54
Submit your next manuscript to BioMed Central and take full advantage of:

- Convenient online submission

- Thorough peer review

- No space constraints or color figure charges

- Immediate publication on acceptance

- Inclusion in PubMed, CAS, Scopus and Google Scholar

- Research which is freely available for redistribution

Submit your manuscript at www.biomedcentral.com/submit
() Biomed Central 